\title{
Być albo nie być? \\ Odnowa strategiczna z perspektywy ewolucyjnej
}

\section{To be or not to be? \\ Strategic renewal from evolutionary perspective}

\author{
Ewa Stańczyk-Hugiet \\ Uniwersytet Ekonomiczny we Wrocławiu, e-mail: ewa.stanczyk@ue.wroc.pl
}

\begin{abstract}
Streszczenie
Celem artykułu jest przedstawienie ewolucyjnego ujęcia procesu odnowy strategicznej ze szczególnym wyeksponowaniem adaptacji organizacji i selekcji ze strony otoczenia oraz koewolucji organizacji i otoczenia na podstawie badań literaturowych. Do zrozumienia odnowy strategicznej istotne jest wyjaśnienie charakterystyki otoczenia współczesnego biznesu, w którym istotną rolę odgrywają przełomowe innowacje, a zmiany określane są kategorią high-velocity. Wykorzystanie perspektywy selekcji oraz adaptacji wskazuje, że ewolucyjna epistemologia podkreśla rolę adaptacji, którą utożsamiono z odnową strategiczną. Z kolei wątek selekcji pozwala wskazać na koewolucję jako ważny proces odnowy organizacyjnej. Jednym z wniosków przeprowadzonych badań jest to, że odnowa strategiczna jest procesem silnie uwarunkowanym zmianami zewnętrznymi i z tego względu tempo zmian wewnętrznych powinno korelować z tempem zmian zewnętrznych.
\end{abstract}

Słowa kluczowe: odnowa strategiczna, adaptacja, dostosowanie.

\begin{abstract}
The purpose of this article is to present an evolutionary approach of strategic renewal process, with exposing specificly organizational adaptation and environmental selection and the coevolution of organization and environment based on the research literature. For an understanding of the strategic renewal it is important to clarify the characteristics of today's business environment, in which an important role is played by disruptive technologies and changes are defined in terms of high-velocity. Using the selection and adaptation perspective suggests that evolutionary epistemology emphasizes the role of adaptation, which equated with strategic renewal. In turn, the selection allows to point the co-evolution as an important organizational renewal process. One of the conclusions of this study is that strategic renewal is strongly conditioned by external changes, and therefore the rate of internal changes should correlate with the rate of external change.
\end{abstract}

Keywords: strategic renewal, adaptation, adjustment. 


\section{Wstęp}

Problematyka zmian to ważny aspekt funkcjonowania organizacji w sensie jej trwania i rozwoju. Odnowa strategiczna to szczególna zmiana umożliwiająca dopasowanie między organizacją a jej kontekstem. Dopasowanie można traktować w kategoriach responsywności albo w kategoriach proaktywności. Najogólniej jednak ma ono znaczącą wartość z perspektywy 'być albo nie być' organizacji. Taka logika skłania do aplikacji epistemologii ewolucyjnej w celu wyjaśnienia zagadnień odnowy strategicznej i odnowy strategii, przy czym ewolucyjna logika uznaje, że czynnikiem sprawczym zmian jest kontekst, utożsamiany z otoczeniem.

Artykuł koncentruje się na procesie odnowy strategicznej z perspektywy ewolucyjnej. Przyjęcie takiej płaszczyzny analizy zagadnienia pozwala spojrzeć na możliwości i ograniczenia procesu inicjowania odnowy strategicznej przez organizacje.

Proces ewolucji, w którym decydujące znaczenie ma selekcja oraz adaptacja, stawia wymagania wobec zarządzających, którzy odgrywają rolę inicjatora zmian w procesie odnowy strategicznej - zmian, które pozwalają przetrwać organizacji.

Celem artykułu jest przedstawienie ewolucyjnego ujęcia procesu odnowy strategicznej, ze szczególnym wyeksponowaniem adaptacji organizacji i selekcji ze strony otoczenia oraz koewolucji organizacji i otoczenia w świetle badań literaturowych.

\section{Kontekst odnowy strategicznej}

Truizmem jest stwierdzenie, że otoczenie organizacji cechuje się częstymi zmianami reguł gry. Powszechny jest także pogląd, że to otoczenie dominuje nad organizacją i w rezultacie organizacja „musi” podporządkować się wpływom otoczenia, aby przetrwać.

Dzisiejszy krajobraz konkurencji charakteryzuje: zwiększająca się strategiczna nieciągłość oraz nierównowaga, rozmyte granice sektorów, hiperkonkurencyjne rynki, ekstremalna presja na cenę, jakość oraz zaspokojenie potrzeb klientów, zwiększający się nacisk na innowacje oraz ciągłe uczenie się oraz zmiana dynamiki karier i oczekiwań pracowników [Hitt, Keats, DeMarie 1998, s. 22-44].

Współczesne procesy zarządzania oraz organizacje stoją w obliczu sytuacji, którą najlepiej opisuje kategoria strategic inflection point [Puffer 1999, s. 15-24]. Konsekwencją strategicznego punktu przełomu jest to, że organizacje konfrontują się ze znaczącymi zmianami w otoczeniu, przy czym przyjmuje się, że taką przełomową zmianą jest wprowadzanie nowych technologii [Jarrosson 2009, s. 46]. Strategiczny punkt przełomu oznacza, że organizacje stają wobec konieczności wprowadzenia często fundamentalnych zmian.

Przeprowadzona przez C. Christensena analiza pozwala na opisanie zjawisk przerywających tok rozwoju (posiłkując się analogią innowacji przełomowych, technologies) [Christensen 2010, s. 24-37]. W obliczu zmian przerywających tok rozwoju nie wystarczy po prostu reagować, konieczne jest wcześniejsze rozpoznanie sytuacji, które jest niezwykle trudne z uwagi na cechy wskazanego zjawiska. Konstatując, C. Christensen [2010, s. 235-262] podaje trzy elementy składające się na model zdolności organizacji w warunkach przełomowych technologii, a mianowicie: zasoby, procesy i wartości. To właśnie te elementy odgrywają decydującą rolę w odniesieniu do tego, czy organizacje są w stanie funkcjonować w sytuacji zmian przerywających tok rozwoju, a tym samym przetrwać.

Wartościowym wyjaśnieniem charakteru współczesnego otoczenia organizacji jest także kategoria otoczenia dużej prędkości (high-velocity environments). Termin ten wywodzi się z badań prowadzonych przez K. Eisenhardt i J. Martina i pozwalają one na uznanie, że właśnie high-velocity - duża prędkość jest właściwym atrybutem otoczenia [Eisenhardt 2000, s. 1105-1121].

Otoczenie dużej prędkości charakteryzuje szybka, nieciągła i symultaniczna zmiana popytu, konkurentów, technologii i regulacji. To właśnie te, przyjęte przez L. Bourgeois i K. Eisenhardt [1988, s. 816-835], charakterystyki pozwalają na zaakceptowanie założeń odnoszących się do właściwości informacji, a więc tego, że informacja jest temporalna, nieprecyzyjna, a nawet po prostu niedostępna. Dynamiczne zmiany latentne [Brown, Eisenhardt 1998] nadają prędkość otoczeniu i dowiedziono, podobnie jak C. Christensen, że są to zmiany technologiczne. W otoczeniu dużej prędkości występuje ciągły dynamizm, którego cechą jest gwałtowna zmiana nieciągła. Rezultatem tego dynamizmu jest [Eisenhardt 1989, s. 543-576]:

- rozmycie granic organizacji,

- dysfunkcjonalność modeli biznesu dotąd cenionych ze względu na swą efektywność,

- ciągła zmienność ról poszczególnych uczestników rynku,

- spowolnienie procesów decyzyjnych.

W otoczeniu dużej prędkości złożone i nieprzewidywalne zmiany są częste i przejawiają się w postaci wstrząsów rynkowych [Hart, Banbury 1994, s. 251-269]. Zwiększona złożoność sprawia, że zarządzający przy formułowaniu strategii mają do dyspozycji i muszą sobie radzić z ogromną liczbą zmiennych odnoszących się do otoczenia konkurencyjnego. Ponadto wymagana jest wysoka elastyczność organizacji w konfrontacji z dynamiką otoczenia i ograniczonymi możliwościami prognozowania [Bogner, Barr 2000, s. 212-226].

Zarysowana wcześniej charakterystyka otoczenia kieruje uwagę $\mathrm{w}$ stronę istoty relacji między organizacją a otoczeniem, a szczególnie w stronę perspektywy adaptacyjnej, czy tzw. teorii racjonalnej adaptacji, która często określana jest teorią przetrwania najlepiej dopasowanego. Immanencją adaptacji jest rekonfigurowanie zasobów spójne ze strategią w celu osiągnięcia stanu dopasowania do zmian otoczenia [Chakravarthy 1982, s. 35-44]. Teoria adaptacji eksponuje znaczenie posiadania przez organizację zdolności do adaptowania do zmian w otoczeniu, zdolności do systematycznego dostosowywania się do tych zmian. Stawiane jest tu przypuszczenie, że organizacje mogą (mają zdolność do) rozpoznawać otoczenie, interpretować problemy i zmieniać swą wewnętrzną organizację, co warunkuje ich przetrwanie.

Teoria racjonalnej adaptacji, a także m.in. teoria zależności od zasobów i teoria ekologii populacji w podobny sposób wyjaś- 
niają relacje między organizacją a otoczeniem, podkreślając, że otoczenie jest inwariantnym czynnikiem ograniczającym organizacje.

K. Smith i Q. Cao [2007, s. 329-344] przedstawiają odmienny od powyższych sposób wyjaśniania relacji między organizacją a otoczeniem. W tej koncepcji dominuje założenie, iż czasami menedżerowie są w stanie kreować zmiany w otoczeniu. Podkreśla się tu znaczenie możliwości poznania oraz systemów przekonań w odniesieniu nie tylko do menedżerów, ale i uczestników rynku w celu wyjaśnienia, jak działa organizacja i jak, w sytuacji sprzyjającej, mogą oni kształtować i wpływać na otoczenie. Odpowiedzi poszukuje się w wyszukiwaniu i podejmowaniu przez menedżerów działań przedsiębiorczych oraz $\mathrm{w}$ procesach uczenia się sprawiających, że zmienia się system przekonań zarówno menedżerów, jak i uczestników rynku.

Jeśli weźmie się pod uwagę opisane wcześniej uwarunkowania, to widać, że organizacje są niejako zmuszone do zmiany myślenia w zakresie pozycjonowania rynkowego i strategii kreowania wartości. To prowadzi do procesów odnowy strategicznej.

\section{Odnowa strategiczna jako przejaw adaptacji}

Badania w obszarze odnowy organizacyjnej koncentrują się głównie na wnętrzu organizacji, co jest dość zrozumiałe, ponieważ istotą zagadnienia jest zmiana, która dokonuje się właśnie wewnątrz. Przez odnowę przedsiębiorstwa należy rozumieć proces, treść i efekt wymiany kluczowych elementów modelu biznesowego [Cyfert 2012].

Z kolei odnowa strategiczna, w mojej opinii, oznacza nieco inny wymiar analizowania zagadnienia. $\mathrm{W}$ tym względzie przydatne jest rozumienie procedury odnowy przedsiębiorstwa, jaką przyjmują R. Agarwal i C. Helfat [2009, s. 281-293]. Według tych autorek odnowa przedsiębiorstwa jest połączeniem procesu, treści oraz efektów przebudowy lub zastąpienia tych elementów przedsiębiorstwa, które mogą znacząco wpłynąć na jego wyniki w dalszej perspektywie i są kluczowe dla zdolności adaptacyjnych danego przedsiębiorstwa.

Zatem, inaczej patrząc na te kwestie, można uznać, że odnowa przedsiębiorstwa jest procesem adaptowania się przedsiębiorstwa do kontekstu. Zdolności adaptacyjne, a zwłaszcza absorpcyjne, są kluczowe dla skuteczności procesu odnowy, tym samym warunkują, oczywiście w pewnym zakresie, adaptację przedsiębiorstwa. Ten ograniczony zakres adaptacji wynika z natury otoczenia, które decyduje o przetrwaniu przedsiębiorstw, w ten sposób oceniając, które z nich najlepiej adaptują się do warunków.

W zarządzaniu strategicznym dominuje przekonanie, że aby organizacja przetrwała w długim czasie, musi być dopasowana do otoczenia. Takie pojmowanie zagadnienia sugeruje, że organizacja powinna w możliwie najlepszy sposób dopasowywać procesy odnowy strategicznej do szans i zagrożeń w otoczeniu zewnętrznym. W literaturze przedmiotu toczy się dyskusja dotycząca tego, czy organizacja jest w stanie dokonać samoodno- wy w celu utrzymania dopasowania w długim czasie, czy może nie. Część badaczy stoi na stanowisku, że organizacje nie są zdolne do przeprowadzenia odnowy strategicznej i są coraz bardziej inercyjne w miarę upływu czasu ich funkcjonowania i wzrostu. Inni wskazują wiele przykładów rzeczywiście istniejących organizacji, które dowodzą, że organizacje mogą skutecznie podtrzymywać swoją przewagę konkurencyjną w obliczu zmian poprzez właśnie strategiczną odnowę [Lewin, Volberda 1999, s. 519-535]. Jednocześnie podkreśla się, że fundamentalna odnowa strategiczna istotnie oddziałuje na zdolności, rutynę i praktyki obecne w codziennym funkcjonowaniu organizacji.

M. Hannan i J. Freeman [1987, s. 910-934] sugerują, że rozwiązanie tego problemu (opozycji) powinno być poszukiwane w kontekście temporalnym. W miejsce zakładania, że organizacja jest $\mathrm{z}$ zasady niezdolna do odnowy $\mathrm{w}$ obliczu zmian w otoczeniu, twierdzą, że źródłem niepowodzenia procesów odnowy jest odchylenie tempa zmian organizacyjnych od temporalnego wzorca zmian w otoczeniu (tzw. inercja relacyjna). Podobnie, m.in. H. Volberda i A. Lewin [2003, s. 2111-2136], uważają, że przetrwanie organizacji związane jest z zarządzaniem wewnętrznym tempem zmian, aby było równe lub nawet wyższe od zewnętrznego tempa zmian.

Należy podkreślić, że dla zrozumienia procesu strategicznej odnowy niezbędne staje się odseparowanie temporalne strategicznych i operacyjnych aspektów procesu odnowy strategicznej. Badania prowadzone $\mathrm{w}$ obszarze odnowy strategicznej wskazują bowiem, że głównym problemem w tym procesie jest rozproszenie uwagi.

Jak wcześniej zaznaczono, przetrwanie organizacji determinuje utrzymanie dynamicznego dopasowania między organizacją a jej otoczeniem. Jednak warto wskazać na dwie inne perspektywy pojmowania owego dopasowania, którymi są: selekcja przez otoczenie i organizacyjna adaptacja. Podstawowa różnica między tymi podejściami tkwi w zakresie, w którym, jak się zakłada, firma jest zdolna do odnowy strategicznej w obliczu zmian egzogenicznych.

Perspektywa selekcji przez otoczenie podkreśla, że to czynniki zewnętrzne określają, jakie cechy organizacji najlepiej pasują do otoczenia, a organizacja jest ograniczona w działaniu wyłącznie do doskonalenia istniejących praktyk (rutyny), które, w efekcie, są źródłem inercji. Podczas gdy te praktyki (rutyna) nadają firmie zdolności do poszukiwania, to także tłumią koncentrację uwagi i ograniczają zdolności do absorbowania nowych informacji, ponieważ nadają priorytet rozwiązaniom, które są efektem wcześniejszych doświadczeń. Mniej deterministyczne ujęcie tej perspektywy uznaje, że można zmieniać organizację tak, aby osiągnąć dopasowanie, ale tylko jako odpowiedź na zmianę zewnętrzną (dopasowanie responsywne). Co więcej, z tego punktu widzenia zakłada się, że organizacje na ogół nie są w stanie dopasować wewnętrznego tempa zmian do temporalnych wzorców zmian w otoczeniu.

Natomiast perspektywa adaptacji odchodzi od założenia, że organizacja nie jest w stanie przezwyciężyć skostnienia i jednocześnie dowodzi, że odnowa strategiczna może być jednak osiągnięta poprzez intencjonalny proces zarządzania [Child 
1972, s. 1-22]. W tym aspekcie przyjmuje się, że menedżerowie aktywnie zarządzają zdolnościami do absorbowania nowej wiedzy. Oprócz zmiany strategii w odpowiedzi na zmiany zewnętrzne, próbują konstruować i kształtować otoczenie przedsiębiorstwa w celu osiągania własnych korzyści. Oznacza to, że firmy mogą zachowywać się proaktywnie w dążeniu do dopasowania (dopasowanie proaktywne) (por. [Eisenhardt, Martin 2000; Nelson, Winter 1982]).

Łącząc perspektywy selekcji i adaptacji, autorzy publikacji [Ben-Menahem et al. 2013, s. 216-235] podają argumenty za tym, że z czasem odnowa strategiczna wymaga dokonania oceny tempa zmian na rzecz odnowy strategicznej w relacji do tempa zmian w otoczeniu. Co ciekawe, ten temporalny wymiar odnowy strategicznej pozostaje ciągle niedostatecznie zbadany. Obecne badania wskazują, że jedynie ogólnie tempo zmian w otoczeniu organizacji biznesowych silnie wpływa na tempo operacji i procesów wewnętrznych. S. Nadkarni i V. Narayanan [2007, s. 243-270], eksplorując tzw. odwrotną przyczynowość, twierdzą, że tempo zmian w otoczeniu powinno być traktowane jako wzorzec dla zbiorowych przekonań i zagregowanych działań poszczególnych organizacji. Natomiast H. Volberda i A. Levin [2003, s. 2111-2136] sugerują raczej, że wewnętrzne i zewnętrzne tempo zmian koewoluuje.

Deterministyczne podejście badawcze przyjmuje, że relacje $\mathrm{z}$ otoczeniem są w sposób naturalny ograniczeniem swobody działania przedsiębiorstw, gdyż w ich wyniku są one zmuszone do adaptowania się i uwzględniania wpływów otoczenia.

H. Hakansson i I. Snehota [2006, s. 257-258], wyjaśniając problematykę strategii, wskazują na trzy podstawowe założenia kształtujące sposób myślenia o strategii, a dotyczące natury procesu adaptowania się do otoczenia z perspektywy strategii.

Po pierwsze, otoczenie nie ma granic, nie jest atomistyczne i jest poza kontrolą ze strony organizacji. Drugie ważne założenie dotyczące strategii odnosi się do wykorzystania zasobów kontrolowanych przez kontrakty. W niepoddającym się kontroli otoczeniu efektywność czy potencjał wymiany są uzależnione od relatywnej efektywności tworzenia kombinacji zasobów. Zasoby wewnętrzne mogą być realokowane po to, by adaptować się do warunków zewnętrznych i podnosić efektywność. Po trzecie, zewnętrzne uwarunkowania zmieniają się w sposób ciągły, co sprawia, że procesy adaptacji powinny być ciągłe.

Adaptacja może być skoncentrowana na wnętrzu organizacji, w celu zaproponowania rozwiązań organizacyjnych, które zostaną zaakceptowane przez otoczenie. Ze strategicznego punktu widzenia odnowa modelu biznesu jest egzemplifikacją adaptacji. Czynnikami adaptacji są przede wszystkim: eksploatacja, eksploracja możliwości, zdolności absorpcyjne oraz path dependence [Levin, Volberda 1999, s. 529]. Adaptacja jest także zdeterminowana posiadanym zbiorem rutynowych zachowań organizacyjnych, idiosynkratycznym uczeniem się, zbiorem unikatowych zasobów.

$\mathrm{Z}$ jednej strony w procesie odnowy strategicznej pojawia się obawa przed nieznanym, co wpływa na strukturyzowanie wszystkiego i poszukiwanie prostej logiki w miejsce złożonej.
W efekcie obserwowane jest przywiązanie do dotychczasowych rozwiązań, procedur itp., co dobrze wyjaśnia teoria inercji strukturalnej.

Z drugiej strony system może się dostosowywać (adaptować) do rodzaju i poziomu zakłóceń, czyli skutecznie przeprowadzać procesy odnowy strategicznej. Wymagana (niezbędna) jest wówczas elastyczność systemu, sprawiająca, że jest on zdolny do dopasowania się do całej gamy bodźców płynących $\mathrm{z}$ otoczenia, często bez zasadniczej zmiany istoty swego działania.

Zatem napięcie między porządkiem wyrażającym się w trwałości i standaryzacji a chaosem wywoływanym przez elastyczność staje się zjawiskiem naturalnym.

\section{Odnowa strategii}

Odnowa strategiczna to przede wszystkim zmiany w strategii organizacji. Oczywiście zmiany te muszą być powiązane z elementami modelu biznesu. Odnowa strategii jest ujmowana jako proces charakteryzujący się złożonością i w konsekwencji będący słabo ustrukturyzowany. Ponadto jest to proces długotrwały, inkrementalny i wielopoziomowy [Martens i in. 2012, s. 720-728].

Wielu autorów postrzega odnowę strategii jako proces ewolucyjny. Na przykład autorzy [Huff, Huff, Thomas 1992, s. 55-75] proponują ujęcie tego procesu w postaci etapów, między którymi organizacja się porusza, a mianowicie etapu podtrzymywania odnowy oraz etapu radykalnej odnowy. Charakteryzują wysiłki na rzecz odnowy jako praktycznie ciągłe oraz wskazują na podstawowe mechanizmy dynamiki odnowy w kategoriach napięcia między inercją i presją. Z kolei M. Crossan i I. Berdrow [2003, s. 1087-105] opisują odnowę strategiczną jako pełen wyzwań proces, w którym występuje napięcie między eksploracją i eksploatacją. Zaproponowali jednocześnie podejście do organizacyjnego uczenia, które umożliwia badanie tego zjawiska. Strategiczna odnowa oznacza ciągły cykl bazujący na intuicji, interpretowaniu, integrowaniu oraz instytucjonalizowaniu (model 4I), powiązany z uczeniem się na bazie feed-forward i feedback. Do tego modelu 0. Jones i A. MacPherson [2006, s. 155-75] dokooptowali kolejne „I” (intertwining), co koresponduje z umiejętnościami międzyorganizacyjnymi, które powinny być rozwijane.

W ogólnym ujęciu literatura odnosząca się do odnowy strategicznej koncentruje się na dwóch wątkach: rozwoju wewnętrznych kompetencji oraz zmianie inkrementalnej, której centralnym punktem jest napięcie między eksploatacją a eksploracją [Martens, Matthyssens, Vandenbempt 2012, s. 720-728].

Strategiczna odnowa to nie tylko zmiana strategii, ale odnowa modelu biznesu. Aby była możliwa, znaczenia nabierają umiejętności, a zwłaszcza (jak dowodzą [Doz, Kokkonen 2010, s. 370-382]) tzw. metazdolności. Wśród tych zdolności wskazują na:

- $\quad$ strategiczną wrażliwość: ostrość postrzegania i intensywna świadomość i dbałość o rozwój strategiczny,

- jedność kierownictwa: zdolność kierownictwa do podejmowania śmiałych, szybkich decyzji, 
- płynność zasobów: wewnętrzne zdolności do rekonfigurowania zdolności i szybkiego realokowania zasobów.

Warunkiem sprzyjającym odnowie strategicznej może być kreatywność czy wręcz twórcza strategia [Dyduch 2014], dzięki której możliwe jest przezwyciężenie inercji. Niewątpliwie ważną rolę odgrywają zdolności przedsiębiorcze, które wiążą mechanizmy adaptacji (zdolności organizacji do podejmowania twórczych decyzji oraz zdolności do organizacyjnego uczenia się) z mechanizmami selekcji (zamierzenia strategiczne, czujność wobec szans, przestrzeganie granic domeny) [Bratnicki 2009, s. 86-92].

Sumując: każda zmiana, w tym również odnowa strategiczna, jest wypadkową dwóch efektów: intencji menedżerów odnoszących się do adaptacji oraz presji otoczenia.

\section{Odnowa strategiczna - perspektywa koewolucji}

Możliwości odnowy strategicznej i jej racjonalność można także wyjaśniać, posiłkując się ekologią populacji, która interpretuje przeżycie organizacji w kategoriach mechanizmów selekcji ze strony otoczenia. Dynamika populacji wyjaśniana jest $\mathrm{w}$ populacji organizacji przede wszystkim z perspektywy pojawiania się innowacji przedsiębiorczych, czyli powstawania nowych organizacji lub adaptacji organizacji już istniejących.

Taki punkt widzenia oznacza, że otoczenie i w rezultacie organizacje koewoluują $\mathrm{w}$ wymiarze rozwoju technologicznego i organizacyjnego. Zmiana na poziomie organizacji ma charakter celowy, a jednocześnie reaktywny, związany z presją na dopasowanie do otoczenia. Oczywiście adaptacja jest ważna dla organizacji, lecz zmiany są warunkowane historycznie ukształtowaną ścieżką rozwoju ze względu na zakorzenione procedury i zestawy działań [Nelson, Winter 1982]. W efekcie możliwości adaptacji są ograniczone. Organizacja i otoczenie wpływają na siebie wzajemnie, a przez to koewoluują.

Adaptacja przybiera więc formę koewolucji, wyrażającą się specyficzną symbiozą. Zawiązywane są więzi, stanowiące bazę realizowania wspólnych działań. Te więzi wywołują samoistne zmiany organizacyjne współpracujących podmiotów (samoorganizacja), podnoszące ogólną sprawność współpracy. Działania o charakterze bardziej spontanicznym i dynamicznym (samoorganizujące się sieci powiązań) są uwarunkowane środowiskowo. Koewolucja służy adaptowaniu się do otoczenia, lecz także adaptowaniu się do siebie w populacji.

Założyć można, że przywództwo w sektorze nie jest wynikiem menedżerskiej adaptacji czy oddziaływania otoczenia, lecz rezultatem osiąganym poprzez wspólne intencjonalne i środowiskowe oddziaływanie. Istotnym ograniczeniem procesów koewolucji jest „efekt Czerwonej Królowej”. W nawiązaniu do badań wielu autorów [Barnett, McKendrick 1994; Voelpel, Leibold, Tekie 2006, s. 37-49] „efekt Czerwonej Królowej” ma pozytywne i negatywne konsekwencje. W drodze inkrementalnych, ciągłych procesów odnowy organizacja uzyskuje przewagę w postaci zdolności strategicznych i poprawy wyników. Jednocześnie wzmacniana jest elastyczność organizacji w obliczu bezpośredniej konfrontacji z konkurentami.
Niemniej jednak organizacja w procesach odnowy może napotkać dwa istotne ograniczenia związane z „efektem Czerwonej Królowej”. Po pierwsze organizacja jest ograniczona swoją historią, czyli tym, czego nauczyła się w przeszłości. Oznacza to najczęściej, że na nowe wyzwania organizacja reaguje, korzystając z puli wypracowanych w odmiennych warunkach praktyk (rutyny). Drugie ograniczenie pojawia się w sytuacji, gdy organizacja konfrontuje się z konkurentami o odmiennych ścieżkach rozwoju. Koewolucyjna adaptacja, a tym samym odnowa, staje się właściwie niemożliwa, a próby adaptacji do nowych konkurentów mogą wymagać także istotnych zmian w odniesieniu do pozostałych podmiotów konkurujących.

Odnowa strategiczna realizowana jest poprzez dostosowywanie. Pogodzenie stabilności i ciągłości z adaptacyjnością możliwe jest dzięki procesom odnowy i wiąże się ze swobodą wyboru ze strony organizacji. Odnowa musi mieć charakter ewolucyjny [Rokita 2011, s. 19]. Ten ewolucyjny charakter nie oznacza, że wystarczy wyłącznie adaptacja reaktywna, to bowiem właśnie proaktywna adaptacja wiąże się ze swobodnym wyborem.

\section{Podsumowanie}

Podsumowując przedstawione rozważania, można postawić wniosek o deterministycznym wpływie otoczenia na model biznesu oraz proces odnowy strategicznej współczesnej organizacji biznesowej. Przyjęta na potrzeby badań epistemologia ewolucyjna pozwala sformułować kolejne wnioski. Podstawowym wnioskiem z badań jest ten, który wskazuje, że odnowa strategiczna jest tożsama z adaptacją organizacji, przy czym $\mathrm{w}$ tym procesie pojawiają się istotne ograniczenia wiązane przede wszystkim z inercją. Równie istotny jest fakt dopasowania tempa zmian wewnętrznych do tempa zmian zewnętrznych. Z tym nierozerwalnie wiąże się wniosek, że odnowa strategiczna jest efektem $\mathrm{z}$ jednej strony intencji menedżerów, $\mathrm{z}$ drugiej zaś presji otoczenia.

Z kolei z perspektywy koewolucji wyłania się konkluzja wyrażana w postaci „efektu Czerwonej Królowej”. Z jednej strony odnowa to ciągła inkrementalna zmiana. Z drugiej strony możliwości tej zmiany ograniczone są przede wszystkim path dependence oraz rutyną.

\section{Literatura}

Agarwal R., Helfat C., 2009, Strategic renewal of organizations, Organization Science, vol. 20, no 2 (March-April).

Barnett W.P., McKendrick, D.G., 2004, Why are some organizations more competitive than others? Evidence from a changing global market, Administrative Science Quarterly, vol. 49, no 4.

Ben-Menahem S., Kwee Z., Volberda H. W., van den Bosch F.A.J., 2013, Strategic renewal over time: The enabling role of potential absorptive capacity in aligning internal and external rates of change, Long Range Planning, vol. 46.

Bogner W.C., Barr P.S., 2000, Making sense in hypercompetitive environments: A cognitive explanation for the persistence of high velocity competition, Organization Science, vol. 11, no 2.

Bourgeois L.J., Eisenhardt K.M., 1998, Strategic decision processes in high velocity environments: Four cases in the microcomputer industry, Management Science, vol. 34, no 7. 
Bratnicki M., 2009, Ujęcie konfiguracyjne przedsiębiorczych zdolności organizacji, Zeszyty Naukowe Uniwersytetu Ekonomicznego w Poznaniu, nr 129.

Brown S., Eisenhardt K., 1998, Competing on the edge: Strategy as structured chaos, Harvard Business School Press, Boston.

Chakravarthy B.S., 1982, Adaptation: Promising metaphor for strategic management, Academy of Management Review, no 7.

Child J., 1972, Organization structure, environment and performance: The role of strategic choice, Sociology, no 6.

Christensen C.M., 2010, Przełomowe innowacje, PWN, Warszawa.

Crossan M.M., Berdrow I., 2003, Organizational learning and strategic renewal, Strategic Management Journal, vol. 24, no 11.

Cyfert Sz., 2012, Systemowy model organizacji: perspektywa procesów odnowy organizacyjnej, [w:] Strategie i mechanizmy odnowy przedsiębiorstw, G. Bełz, Sz. Cyfert (red.), Wyd. Uniwersytetu Ekonomicznego we Wrocławiu, Wrocław.

Doz Y.L., Kokkonen M., 2010, Embedding strategic agility. A leadership agenda for accelerating business model renewal, Long Range Planning, vol. 43.

Dyduch W., 2014, Twórcza strategia organizacji, Wydawnictwo Uniwersytetu Ekonomicznego w Katowicach, Katowice.

Eisenhardt K.M., Martin J.A., 2000, Dynamic capabilities: What are they, Strategic Management Journal, vol. 21, October-November

Eisenhardt K.M., 1989, Making fast strategic decisions in high velocity environments, Academy of Management Journal, vol. 32, no 3.

Håkansson H., Snehota I., 2006, No business is an island: The network concept of business strategy, Scandinavian Journal of Management, no 22 .

Hannam M., Freeman J., 1987, The population ecology of organizations, American Journal of Sociology, vol. 82, no 5.

Hart S., Banbury C., 1994, How strategy-making processes can make a difference, Strategic Management Journal, vol. 15, no 4.

Hitt M.A., Keats B.W., DeMarie S.M., 1998, Navigating in the new competitive landscape: Building strategic flexibility and competitive advantage in the 21st century, Academy of Management Executive, vol. 12 , no 4
Huff J.O., Huff A.S., Thomas H., 1992, Strategic renewal and the interaction of cumulative stress and inertia, Strategic Management Journal, vol. 13 (special issue).

Jarrosson B., 2009, Vers l'économie 2.0, Éditions d'Organisation, Paris.

Jones O., MacPherson A., 2006, Inter-organizational learning and strategic renewal in SMEs. Extending the 4 I Framework, Long Range Planning, vol. 39, no 2 .

Levin A.Y., Volberda H.W., 1999, Prolegomena on coevolution: A framework for research on strategy and new organizational form, Organization Science, no 5.

Martens R., Matthyssens P., Vandenbempt K., 2012, Market strategy renewal as a dynamic incremental process, Journal of Business Research, no 65.

McKelvey B., Aldrich H., 1983, Populations, natural selection, and applied organizational science, Administrative Science Quarterly, vol. 28 , no 1.

Nadkarni S., Narayanan V.K., 2007, Strategic schemas, strategic flexibility, and firm performance: The moderating role of industry clockspeed, Strategic Management Journal, vol. 28, no 3.

Nelson R.R., Winter S.G., 1982, An Evolutionary Theory of Economic Change, Belknap Press, Cambridge.

Puffer S., 1999, Global executive: Intel's Andrew Grove on competitiveness, Academy of Management Executive, vol. 13, no 1.

Rokita J., 2011, Uwarunkowania metodologiczne we współczesnym zarządzaniu, Prace Naukowe Uniwersytetu Ekonomicznego we Wrocławiu, nr 216, seria Nauki o Zarządzaniu, nr 8.

Smith K.G., Cao Q., 2007, An entrepreneurial perspective on the firm-environment relationship, Strategic Entrepreneurship Journal, no 1.

Voelpel S., Leibold M., Tekie E., 2006, Managing purposeful organizational misfit: Exploring the nature of industry and organizational misfit to enable strategic change, Journal of Change Management, vol. 6 , no 3 .

Volberda H.W., Baden-Fuller C., van den Bosch F.A.J., 2001, Mastering strategic renewal: Mobilising renewal journeys in multi-unit firms, Long Range Planning, vol. 34, no 2.

Volberda H.W, Lewin A., 2003, Co-evolution dynamics within and between forms: From evolution to co-evolution, Journal of Management Studies, vol. 40. 